\title{
Diaspora Writings: Epiphany, Emotions and Ethics
}

\author{
Jayshree Singh \\ Bhupal Nobles’ University, Udaipur, Rajasthan, India
}

\begin{abstract}
These writings as an image of adjustments in the host culture of their migrated place, as graphics of invert expectations, as words of subconscious memory and as signs of a flash of insight present social conditioning and pressures of migrants in alien lands, who traversed across cross-borders for some or the other reasons. Migration is mostly an economic, escape, expatriate, exile activity. It encourages cultural inflow and cultural outflow. Migration to abroad indeed brings good-feel factor, but there is emotional crisis of self and nationality. There is a discovery of one's "Self" as the center of human existence and for interdependence. Because of "Videsiya bhav", lots of narratives, memoirs, letters, and travelogues have been written to search roots of nativity, belongingness in their imagination. Besides manifestation, it is the catharsis of their wings/flight. With their spatial paradigms, the novelists go beyond the past. They perceive present by way of imaginary construction of memory, nostalgia, and myth in order to dispossess the past. To remove the sense of otherness, they eliminate western standardization and reorient their cultural tradition. The paper aims to interrogate the human displacement across borders and rupture in relationships. The study attempts to sensitize the migrants' memories and emotional loss and to understand mobility in terms of the social structure and cultural process. It examines Western psyche with Indian psyche in a context of the emotional history of migrants. The stories of emotional disposition, remembrance, missing, searching evoke resilient attitude towards one's own and towards the place they live. Emotion is a child like activity for Indian migrants as well as for those who are left behind in their homeland.
\end{abstract}

Keywords: emotional disposition, narratives, diaspora, geopolitics, migrants, manifestation, cultural values

\section{Diaspora Determining Dimensions}

The writers of Diaspora express their expatriate, immigrant, migratory, dislocated, disoriented, displaced subjectivities and experiences through a continuous flow of ideas, feelings, and thoughts in a stream of consciousness. Their conscious experiences, observations, impressions reoccur from their subconscious mind, memory, desire, menace or apprehensions. The authors articulate their sentiments to project the contemporary circumstance, but basically they demystify the reality of their subconscious mind. That not only suggests the inner anguish but also universalizes the problem through their evolving process of self-consciousness. Their artistic dialogic perception and creative urges establish syllogism between the thinking readers and the autobiographical experiences and consciousness of the novelists. They unleash such exposition through the art of characterization in the story. The novels of the women authors in this paper are the "un-homely, fictions of the world literature" (Bhabha, 1994, p. 12).

The significant aspect of this description is that Diaspora writer is enabling the readers of transnational

Dr. Jayshree Singh, Department of English, Faculty of Social Science and Humanities, Bhupal Nobles’ University. 
boundaries to rethink about the socio-cultural exposition and to legitimize the repressed memories, desires, menace both in terms of gender and change in the transnational context. The textual, intertextual and sub-textual versions of the creative writing sensibly persuade the readers to re-examine the ideology and the real politics of collective consciousness from the platform of Diaspora to determine human symbolically in the first place more than to relocate historical and geographical significance. They want to repossess the worth of valorizing their margin status and as the immigrant, they desire to forget history/the past and hope to look at future with hope by including new practice in the geopolitical order in the complicated network of historical histrionics. We find the division of emotions due to the conflict in the value system of the East and the West. Thus the issue of geopolitics is dealt through emotions.

\section{Jhumpa Lahiri}

Jhumpa Lahiri's Namesake (Indo-American) takes the Ganguli family from their tradition-bound life in Calcutta through their fraught transformation into America. On the heels of their arranged wedding, Ashoka and Ashima Ganguli settle together in Cambridge, Massachusetts. His wife resists all things American and pines for her family. The immigrants face cultural dilemmas in the foreign system and gradually imbibe the cultural ways of the host country too. Their own children groomed to be "bilingual" and "bicultural", face cultural dilemmas and displacement more. The novelist Jhumpa Lahiri in The Namesake manifests the characters suffering from the fallacy of fear, humiliation, and hope. The Indo-US Diaspora writer, present the state of the contemporary generation of Indians who got migrated U.S. to get settled in an alien land after an ordeal of their adjustments in the cultural formations and cultural aspirations. Their children get into those things which their own parents who migrated to the alien country are indifferent to-such as movies, exhibits at museums, good restaurants, and the design of everyday things. They (the U.S. friends of Gogol in Namesake) speak of New York, of stores and neighborhoods and buildings; they either despise or love, with an intimacy and ease that make Gogol feel as if he barely knows the city. Gogol (the son of Ashok and Ashima Ganguli) is unaccustomed to this sort of talks at mealtimes, to the indulgent ritual of the lingering meal, and the pleasant aftermath of bottles and crumbs and empty glasses that clutter the table. This tells something that his friends of the alien country eat every night (Lahiri, 2003, p. 133).

The matter of displaced identity becomes complex during the process of their hybridism in the foreign culture and their incompatible urge to sustain their native cultural realm. The Indians have only featureless images of their imaginary homeland. Jhumpa Lahiri illustrates this in the novel when their (Gogol's) U.S. friends discuss India and its cities: Eventually, the talk turns to India. Gerald asks questions about the recent rise of Hindu Fundamentalism, a topic Gogol knows little about. Lydia talks at length about Indian carpets and miniatures, Maxine about a college class she'd once taken on Buddhist stupas. They have never known a person who has been to Calcutta. Gerald has an Indian colleague at work who just sent to India for his honeymoon. He'd brought back spectacular photographs, of a palace built on a lake. "Was that in Calcutta?" "That's Udaipur," Gogol tells them. I've never been there. Calcutta is to the east, closer to Thailand.” Lydia asks: What's Calcutta like? Is it beautiful?” The question surprises Gogol. "I want to go to Calcutta”, Maxine says, as if this has been a thing denied to her all her life (Lahiri, 2003, pp. 155-156).

Through the abovementioned conversation, the author surfaces the cross-cultural curiosity, cross-cultural exchange, and cross-cultural respect. The dichotomy of differentiation and assimilation is represented not only in textual content, but the semantics of subtext suggests that location of culture and socialization are one of the 
primary areas of reconciliation whether it is on the part of the immigrant or on the part of the citizens of the alien country. There is also reversal and discovery in the dialogues. The U.S. citizens wish to visit India, or they have gathered some primary information about India from their own country visitors to India, whereas the immigrant who is the autobiographical voice of the author tries to relocate the geography of his imaginary homeland, attempts to explain the demographic difference through his meager knowledge, at the same time he understands that his occupancy in alien country has obliterated his own country's history, culture, politics, geography.

Gogol is just like the author Jhumpa Lahiri whose origin was from Calcutta itself, discovers his origin and the real image of India from his subconscious mind during his conversation with his friends. Gogol discovers that his father, who in the emergency of registering his child's name while getting released from the maternity hospital, found a name for his child as "Gogol Ganguli" from The Stories of Nikolai Gogol and then reinvented it as Nikhil Ganguli. Gogol who had been running away from his inherited name and identity in the alien world, discovers the truth of his displaced-self from the same book, when he at the end read the first story "Overcoat" which once saved his father Ashoka to meet with an accident inside the train; his father had his rebirth; similarly Gogol is salvaged from being disarrayed from the lifestyle of New York by that same book in the end of the novel, because this was then the inherited legacy which his father, as an engineer of MIT Boston in U.S. had left for him and for his mother Ashima and sister Sonia to carry on.

Another important instance of remapping the past and the present is described by the author in an autobiographical sense. The mother Ashima, after her husband's death, had accelerated certain expectations for Gogol to get settled. He used to say he was only thirty, she replied that by that time she celebrated her tenth wedding anniversary. 'She makes a point of mentioning the engagements and weddings of the Bengali Children he's grown up within Massachusetts and his cousins in India. She mentions grandchildren being born. The critic says that Lahiri is caught between the socio-cultural nuances of her Indian origin and the American life-ways (Sarangi, 2005, pp. 283-290). In the novel Namesake, Ashoka and Ashima portray Jhumpa Lahiri’s parents' image and their struggle to reinvent their identity in new nation and culture who immigrated to London with her husband.

In the novel, the new and the last girlfriend of Gogol is Moushimi, a hybrid Bengali with a British accent, who lived in New York, doing Ph.D. in French Literature in NYU. This character of the novel represents the past of Jhumpa Lahiri's childhood in London and the later youthful years in America and finally "remembering her native self" (Mehta, 2004, p. 7) during her wedding with Alberto Vourvoulias, an American with Hindu ritual in Calcutta. Jhumpa Lahiri sketches Moushimi’s profile as was explained to Gogol by Moushimi: She speaks with nostalgia of the years her family had spent in England ... She tells him that she hated moving to America, that she had held on to her British accent for as long as she could... She had rebuffed the Indian men she wasn't interested in... She married Gogol but then she wrecked her marriage... (Lahiri, 2003, p. 213)

The significant aspect of this description is that Diaspora writer is enabling the readers of transnational boundaries to rethink about the socio-cultural exposition and to legitimize the repressed memories, desires, menace both in terms of gender and change in the transnational context. The textual, intertextual and sub-textual versions of the creative writing sensibly persuade the readers to re-examine the ideology and the real politics of collective consciousness from the platform of Diaspora to determine human symbolically in the first place more than to relocate historical and geographical significance.

According to a critic James Proctor (2008), the study of the above-mentioned observations from the 
Namesake novel expresses an awareness and intellectual movement-there is ongoing negotiation between dominant and the subordinate group The abandoned culture becomes an object of inquiry as regards cultural identity, style, solution to social and political process The text restructures cultural formation which is beyond economic and material factors in the minds of readers. It marks a shift towards a consideration of the subjective experiences of individuals, and socialized aspirations of groups and communities that complement the traditional modes of analysis of the political and economic systems of which they are apart. The knowledge of acculturation and politics also involves recognition of transnational and often gendered cultural differences and the significance of different forms of knowledge for different communities.

\section{Ramabai Espinet}

The Indo-Trinidadian writer Ramabai Espinet's The Swinging Bridge in 1990 exposes the analysis of Indian construction of female identity not only in Trinidad but also its impact on issues of race, class, sex, gender and nationhood. She has revealed the simultaneous affirmations and negations of Indo-Caribbean women at home and abroad to engage the issues of creolization, exile, personal and communal agency, identity politics and race negotiations (especially with the dominant Afro-Caribbean cultures in Trinidad and Western modernity of Whites in Canada). The author portrays the sense of racism in the tortured family and the feeling of displacement that continuously haunts the central female character. It carries the reader effortlessly from 19th-century India to the cane fields of Trinidad, and the contemporary urban centers of North America. Mona, a young Indo-Caribbean woman who grew up in Trinidad, confronts not only her own turbulent past but the secrets of a winning family history, that begun on the Indian continent almost two centuries ago. The novel explores the Caribbean life, the immigrant experience marked by violence and shame, but also by love and respect. The Swinging Bridge The novelist also explores the many-layered marks of the impoverished Indians who shed their colonial past in their new homeland and re-imagines themselves in the new culture of Trinidad, then of Montreal in North America.

In the novel The Swinging Bridge, the author reflects upon racial and sexual politics. "The women's body was misfed, misinterpreted metaphorically as more than playful” (Showalter, 1985, pp. 331-337) not only amongst natives of a particular society but even in the multicultural pluralistic society. It became more pitiful and severe during their voluntary mobilization to alien land in the form of indentured labourers, in which several destitute, orphaned, single, widowed women transported from Bihar and Uttar Pradesh provinces of India to the alien Caribbean islands of Trinidad and Guyana. Their journey of transgression and ordeal to sustain led them to traverse not only large expanse of water by ship but the Kala Pani crossings (the waters of Atlantic) made them courageous to be self-reliant, to renegotiate their sexual independence and gendered identity. It dissolved the discrimination and patriarchal structures, yet female dislocation and "migratory subjectivities" (author, year, pp. 331-337) became a subject of geopolitical imagination and confrontation. The novel illustrates the divide between blackness and indigeneity of Indians on the Caribbean islands and the spatial-temporal cultural distance from Canada. In all these configurations, women's position determined a paradigm shift in envisioning "Third World Feminist Struggles, suggesting political rather than biological or cultural basis for diasporic alliances” (Mehta, 2004, p. 11).

Mona the narrator revamps the past history and memories of Indo-Caribbean indentured labourers as ancestors. She is an immigrant from Caribbean islands to Canada. She epitomizes linking migratory subjectivity. She is commensurate with the present generation of the Indo-Caribbean Canadian immigrants. She, 
in her process of making a documentary in order to have a paradigmatic shift from one place to another alien land for better future prospects, explicates the continued state of marginalization, oppression, and suppression on account of their gender and sexuality. She explores that "her great-grandmother Gainder was the girl who had escaped an unwanted marriage, thirteen years old then, arrived on the islands of Trinidad, While on the Ship called 'Artist' consisting of cargo of coolies, the captain of the ship tried to assault her, but then an Indian coolie named Jeevan protected her from being victimized (Espinet,114-115). Gainder, on arriving at Trinidad, sent to Petit Morne estate near the little town called the Mission in the South of the island, the very heartland of sugarcane production. Her talent for singing and composing soon becomes known and she begins to earn extra money as the performer. She tries to get the land allocation promised in her contract, but the estate refuses to encourage single women to live alone and will not give it to her, even though it is her due. When a young Indian man, educated through the missionary enterprise, a money-lender in Iere village made Gainder an offer of marriage after hearing her story. She brought her earnings as a dowry to her new life in Joshua's mother Iere Village. She let herself subjected to the big plans of her husband. When after the full month of her wedding, Joshua told Gainder that she must never sing or dance in public again. Her heart turns to stone when she hears these words (Espinet, 2004, pp. 241-243).

In this detail description, Gainder courageously defied Hindu patriarchal laws that spread social pollution against Hindu women in India as they were in minority and victims of family abuse and communal traditions. She in search of gendered identity renegotiated structural dissolutions of religion, class, caste, sex and gender during the transatlantic displacements. Gainder, her daughter Lily, then Lily’s daughter Muddie and last Mona all these women of four generations "seized the opportunity to transcend their marginality within the nuclear Hindu family by embracing a more expansive Indian diasporic community” (Mehta, 2004, p. 5).

The cultural shift among Indo-Caribbean is visible in this illustration of Grandma Lil. There was a confrontation between past Hindu Laws against women and the modern system of educating girls in missionary schools to be better housewives in elite Indo-Trinidadian families. Women even after facing harassment, violence and family abuse made space for their sexual independence and for determining their space in property business matters. The character sketch of Gainder and Lily highlights "diasporic geopolitics in the context of spatial practices and spatial representations” (Dalby, 1998, p. 87). The writers like Ramabai Espinet through the novel The Swinging Bridge "resists rigid patterns of socialization imposed on them by Hindu patriarchy in the name of cultural integrity” (Mehta, 2004, p. 7). Their self-consciousness revivifies social liberation and social transformation in geopolitical discourse and in the global frame because of cultural transfusion, Western education, and Western modernity.

Da-Da the father of the narrator Mona when migrated to Canada for better prospects without looking into the subjectivities of the women in family, retrospect his,

...early days in Canada and how hard it was for him to make the decision to leave Trinidad, Canada appeared to them a land of missionaries and snow and Wabun the wolf dog, deep and sudden. He left Trinidad to escape from a black African government, because it threatened to confiscate the Rajput fortune” (Espinet, 2004, p. 221)

The fear of Creoleness among Indians was so nightmarish that the Indian girls were not allowed to follow fashion and love-making with the people outside their community. Only the betraying daughters asserting their like Susie dating Kemal a Muslim boy and Mona dating Bree, a Creole boy were an aberration to Hindu families. 
The difference that Mona found against Creolisation, which was elicited by Muddie, her mother who when informed by Grandma Lil that Mona used to date a Creole boy every day, the mother reacted and said to Mona; "Before you study your books, you studying boy. And a Creole boy too! What will happen to you?" (Espinet, 2004, p. 187) Her father Da-Da regretted his hasty decision to leave Trinidad and justifies the truth of his fear about Mona's relationship with a Creole boy.

Another difference that she came across during her interaction with Bree regarding the rule of Black leader in Trinidad, she reiterated the aggressive tone of her friend Susie against the black leader's ideology and spoke "Who? Who de hell is De Doctah to tell me what to do? Who?” This situation led to an exchange of sharp slap on each other's face, although it happened in mere impulsive response, yet that fear lingered and distanced the relationships and communication among the Blacks and Indians in Trinidad. Mona writes: "Years later when Bree and I met again in New York, we talked of neither the future nor the past. We listened to jazz in a juke joint, pressing our legs together, held hands, laughed and talked” (Espinet, 2004, p. 91). This transition in the cultural shift occupies a space from the point of gender and change in the transnational context because it liberates the margins from the ambivalence of their migration journeys and oscillates the binary opposition between displacement and migratory subjectivity.

Spatial manipulations were achieved by settling down the variety of Indians into one colonial culture through transportation, education, plantation work and celebration of their respective cultural traditions. But at the same time spatial segregation could be observed in gender politics when old Hindu widows work as maidservants, not allowed to live life as their choice, they faced sexual assault at night by the politics of power at night, while during day they seemed to be continuing Hindu tradition in temples chanting the verses of Ramayana, serving as labourers. Spatial manipulation was done to educate girls to have better upbringing of the children of the colonized people in order to mobilize and to expand horizons of imperialism. The spatial segregation as per colonized and patriarchal norms of communal traditions were there in the identity politics that no women whether married or single could demand her rights in property and enfranchisement. The girls, wives, and women were beaten as slaves on following any Western trend in life and ways. Spatial manipulation was the target of imperial designs while spatial segregation was the weapon to defend the rule and power in the colonial era.

\section{Anita Desai}

Anita Desai's Bye-Bye Blackbird is about migrant Indians in the England of 1960s. Adit lives in London with his English wife, Sarah. Dev is a newly arrived immigrant from India. Adit has well adjusted himself in the country of his adoption and has allayed his sense of loneliness by being nonchalant to its various causes. Dev, on the other hand, is critical of Adit's attitude. He gets disturbed and angry when someone whispers the word "wog” behind his back. Obviously Dev has more reasons to be lonely and thus when he ventures into the city he feels, "like a Kafka stranger wandering through the dark labyrinth of a prison" (Desai, 2001a, p. 169). Dev's loneliness eventually stops haunting him and he decides to stay in England. Adit, in the interim, suffers from a crisis of identity. He starts longing for the land and the people he has left behind. He feels depressed of “Mrs. Roscommon-James’ sniffs and barks and Dev’s angry sarcasm” (Desai, 2001a, p. 176) as well as from the fact that Sarah "had shut him out, with a bang and a snap, from her childhood of one-eared pandas and large jigsaw puzzles” (Desai, 2001a, p. 176). He finally decides to return to India with Sarah. What this proves is that the sense of loneliness is not a phenomenon of overpowering presence but rather of intermittent overpowering, 
guided by circumstances incidental and always in flux.

Anita Desai's Fasting, Feasting, as it is implied in the title itself, is a novel of contrast between two cultures, the one, Indian, known for its pious and longstanding customs representing fasting and the other, American, a country of opulence and sumptuousness epitomizing feasting. The plot unveils through the perceptions of Uma, in India, and of Arun, in America (Ravichandran: 2014). Just as the United Kingdom, the United States of America has also attracted Indians as a destination of academic and economic prosperity. The size of the Indian Diaspora community in the US is gradually increasing in the post-globalization era. But it is quite debatable to assert that globalization has solved the problems of the Diaspora Indians. No doubt, problems like racism are no longer as headstrong as before, but the problems of the inner "human condition" still plague the diasporic community. Arun, from the novel Fasting, Feasting is a very good example of an Indian in the suburbs of Massachusetts, finding himself lonely and unable to adjust to a culture of freedom. He is not only bewildered by American college life but also by the ways of the Patton family, his host for the summer. He cannot understand the passion with which Mr. Patton himself barbecues red meat after coming home early only to find his son Rod and daughter Melanie absent from the ceremony. He finds it strange that Mrs. Patton keeps her refrigerator always stocked to the full, despite knowing that there are not many heads in her family to consume that food. Arun cannot even identify with Rod and Melanie. Though Arun takes up jogging like Rod, unlike him he simply cannot devote himself to such physical exercise. Arun is appalled to find Melanie's condition of bulimia amidst the plenty that America provides. All dysfunctional indulgences of Americans make Arun puzzled and from this puzzlement, he breeds his sense of loneliness. Faced with a seeming paradox of a new culture, he is lonely.

An inviting doorway does not mean that the heart inside can make one feel like home, especially when the idea of home and family differs from culture to culture. This difference is not fundamental; it is superficial. But so are all cross-cultural conflicts and paradoxes. The first encounter that any migrant has with his/her country of adoption is with superficialities. It definitely takes a time to scratch this surface of superficiality and till then it is only loneliness for the company. Arun tries to seep in through the surface for he knows that the meeting place for two cultures can only be some middle ground. To reach this middle ground he has to assuage the distance that he has to travel, for which he has to know the distance of the other extremity. Arun does so by delving deep into the core of a suburban American family and invariably he is shocked at his first encounter. He takes the first step in overcoming his state of shock by giving to Mrs. Patton as parting gifts, the parcels that have been sent to him by his parents from India (Saha: 2014.).

Anita Desai's Baumgartner's Bombay (1988) deals with the character of a migrant Austrian Jew in Indial. Anita Desai's fictions are generally existentialist studies of individuals and hence background, political, historicity, social settings, class, cross-cultural pluralities are all only incidental. But being incidental does not mean that they are essentially extraneous. Their study is not only as important as the study of "human condition" in Desai's fiction but in fact, they are intrinsic to the latter study. Basically, it is the tension between what is to be included and what to be excluded from the study of the literary text that makes it all the more interesting. This is especially relevant when the fiction deals with the condition of being in a Diaspora about migrant existence. The feeling of loneliness that Desai depicts in her diasporic characters is a result of the inner psyche of the characters as well as also their external circumstances. Loneliness is a manifestation of both inner and outer conditions and hence, it has evoked among readers of global society sentiments to understand their life from the perspective of intercultural unity, rather as the cultural difference. The writer's revelation through 
creative imitation let the readers feel an insight into the spiritual prowess of the writer who brings out recollections about homeland, observations, impressions for the host country and imagination with sensibility with regard to acculturation, acclimatization, and assimilation. The novelist implies with words and symbols the internal and external opposition as well as coordination to survive with brighter pathways.

The Jew, Hugo Baumgartner in the novel Baumgartner's Bombay had spent his childhood in his native Germany with his parents. Even as a child a sense of loneliness gnaws at his being and is evoked at his crucial moments of triumph. On his first day at school when his mother comes to fetch him with a cone of bonbons for him, he holds up his prize for the others to see but already "the other children were vanishing down the street" and "no one saw his triumph". He accuses his mother of being late and complains: "You don't look like everyone else's mother” (Desai, 1998, p. 33). Hugo's loneliness as a child, in the midst of society, comes because of the lack of identification. Even when he is not neglected he feels the same loneliness as is evident from the Christmas incident in the school when all his classmates were sent gifts by their parents to be distributed to them by their teacher. Hugo longs for the red glass globe that adorns the top of the Christmas tree. When the teacher makes it up as his gift he instinctively realizes that his parents have not sent any gift for him and he stubbornly disinclines from accepting it even though goaded by his classmates to take it. It is perhaps this sense of loneliness experienced by the Jewish community in Germany that helped Hitler fuel his Aryan myth and transform loneliness into fear. The Baumgartner family lives in fear in Nazi Germany and fear is an acute form of loneliness.

Long before Hugo has a literal displacement after the suicide of his father, he has experienced a displacement whereby he has not literally moved but the world around him has moved or rather changed. So when Hugo has a physical displacement and migrates as a teenager to India, he already harbors the sense of loneliness. Thus it seems that the change in location is only incidental to his sense of solitariness. But the circumstantial changes also help to aggravate one's solitude and hence it is not merely incidental and this fact is quite apt in consideration with the estrangement that Hugo suffers from his mother. That Hugo's mother stayed back in Nazi Germany and her highly censored letters only bear the court statement that she was well and it provides no comfort to Baumgartner. The memory of his mother in Germany is a constant deterrent against stopping him from succumbing to a sense of loneliness.

Influences and counter-influences that mould one's perceptions govern human life. When the tension generated by these counteracting influences rises to a critical level, human beings suffer. The molding gives rise to senses that off late were in a latent state. Thus Baumgartner's loneliness is also aroused from latency when in India he is in the loneliness-alleviating company of Lotte, a German cabaret singer. Hugo's relationship with Lotte is no doubt vital but acts only as a poor substitute for all the relationships he craves for. Just as Baumgartner keeps stray cats and cares for them in an attempt to give some purpose to his lonely existence, his relationship with Lotte can be thought to be in parallel to it. The relationship in itself is important but it is more important because it gives some purpose to Hugo's "Sisyphus-like" (Taneja, 1991, p. 37) existence as explicated by G. R. Taneja in the essay “Anita Desai’s Baumgartner’s Bombay: A Note”.

At the height of Second World War, Baumgartner is interned in a camp in British India because he carries a German passport. In the camp, Baumgartner is among other Jews yet he stays aloof because he, unlike others, could find no way "to alleviate the burden, the tedium, the emptiness of the waiting days" (Desai, 1998, p. 125). Even after the war, when he meets one of his camp-mates, he finds that he has changed his name from the "too Jewish” Julius to the "very English” Julian. If Julius deliberately dilutes his Jewish identity, Baumgartner 
unknowingly suffers from an identity crisis and to counter it, there arises in him a sense of non-belonging. The Second World War rendered the Jewish Diaspora nationless and hence identity crisis becomes inherent in the community. Baumgartner cannot go back to Germany because the Germany of his childhood no longer exists and hence his perennial sense of loneliness continues. The only time that Baumgartner tries to reconcile the Germany of his childhood with the present-day Germany by taking a stoned German youth, Kurt, to his apartment, he is robbed and murdered by him. It is perhaps the ultimate indictment that no reconciliation is possible and all attempts to wipe out the sense of diasporic loneliness are futile.

In this context, a critic writes:

...the writer in their narrative method illustrates the place or city to unfold their lies, haunts, their dreams, and indeed shapes the stories they tell about their own transitoriness and detachment from the culture that they left behind. This process helps each Diaspora writer to compare and contrast with the past. It is here the importance of the physical city in which the writer lives in becomes significant. (Somdatta, 2007, pp. 118-122)

The German, Kurt, follows the typically decadent lifestyle of the hippies in India but another German, Sophie, from Anita Desai's Journey to Ithaca is most unlike in that regard. She has come to India following her Italian husband, Matteo, who is seeking spiritual love. Sophie cannot identify with Matteo’s ideals and does not find the Mother as inspiring as Matteo does. She is left neglected and lonely in a foreign land. It is quite ironic when Sophie discovers that the Mother herself is a seeker of divine love and is of Egyptian origin who has traveled all over the world until settling in India. But by the time she comes to make the revelation to Matteo, the Mother is already dead and Matteo has disappeared. She has left stranded bearing in her the sense of spiritual loneliness that has come out of the mysticism in the churning of differing cultures.

\section{Chitra Banerjee Divakaruni}

Chitra Banerjee Divakaruni's The Mistress of Spices (1997) metaphorically states the condition of the Mistress of Spices. In alien land America, she turns out to be a tangible asset in terms of knowledge beyond science, but in terms of manifesting relationship she becomes handicapped due to two reasons-first, if any mistress goes beyond her limits, then the spices ordain punishment and as penalty she has to return to the remote island of spices. As per Indian mythical norms, the mistress of spices cannot involve herself in any sort of relationship with customers. Second, the myth of Tilottama and Indian Spices in the cross-cultural context undergoes metamorphosis due to the blend of Orient and Occidental culture and the novelist recreates their relevance in view of acculturation and traditional significance of spices in the life of travelers, explorers, and settlers. The spices always act in Tilo's personal choices like foreign bodies. Spices just like Indian patriarchal societal pattern seem restricting her from her efforts of self-enhancement in a foreign location. Implicitly Indian spices act like men, who believe that it is their right to keep an eye on a woman. Tilo is bound with morality, law, and codes. But Tilo's desire to help others led her to cross her physical and mental boundaries; subsequently she goes out to fulfill her dreams in the Land of Opportunities and Promises i.e., She muses- "Today I plan to stretch my wings, to crack perhaps these shells and emerge into the infinite spaces of the outside world” (Divakaruni, 2005, p. 125). Tile does not have any intention to betray the Spices and her art, but their reaction causes ambiguity in her mind as regards her allegiance to Occultism, to Indianness and to her Diagnosis. Her transgression in the form of sexual intimacy for a day with an American let her surrender to her Spices, and Spices in angst wanted to blaze in Shampati's fire, but just then an Earthquake hits America and finally is saved from being consumed by fire and to lose her magical power of occultism. In this way, her 
surrender to Spices saved her from the penalty and to gain her love too. Chitra Divakaruni through this novel sends the message to transnationals that human beings have the power of recreating an earthly paradise through their constructive actions. Lara Merlin in this situation opines that "Tilo is forced to rethink her role as a healer beyond the simplistic split between her desires to help others and to help herself. In doing so, she conjures up a new American identity” (1998, p. 207). In the end of the novel, Tilo and Raven returns to Oakland. She names herself as 'Maya' which means mythically as an illusion, spell-binding power. She settles and continues her magical art of therapy as a normal occupation in America (Singh \& Chhavi, 2015, p. 316).

\section{Amitav Ghosh}

Amitav Ghosh's Sea of Poppies (2008) allegorically refers the Borders of seas and rivers in the context of cultural memory and constructing homelands that evasively hold the center in the lives of migrants especially for those whose life had envisioned other dreams but circumstances changed their course of life. For the woman character Deeti. Her hut in the village of Gazipur was like a "tiny raft floating upon a river of poppies" (pp. 28-29). Symbolically the river Karmanashak had significance. It was a tributary of the Ganges, which joins with the great river Brahmaputra that finally culminates in the Bay of Bengal. River Karmanashak washed of Deeti's past and re-emergence sanctified her "self". She ventured into a new path of survival after salvaging her life from inherent casteism of Hindu Society and from being burnt on the funeral pyre of her dead husband. She along with her low caste companion and savior ferried from Chappar Ghat to Hoogly through a town Pulawar and joined the bands of migrants on a giant schooner IBIS as coolies. When they had to cross the Kalapani (that is they sailed through Hoogly river and crossed the Bay of Bengal, moved towards East Asia and went beyond the socially attributed margins of the River Ganga that had its manmade defined boundaries in the sacred Jabudva in the 1830s), it was considered against the religious faith as it was believed that migrants have become impure after crossing it. The schooner not only comprised of these homeless, rootless Jahaji Bhais and Jahaji Behens, but also Gazipur opium factory workers, colonized convicted prisoners as slaves, besides consisting of American sailors, French runaways, merharus (Indian women), quoddies, maistries, bhnadaries, gomustas, garmityas, silahdars, lascars, coolies, rajas, sahibs etc. The opium trade used to flourish in the 19th century within the Eastern Sea borders of Subcontinent India and China. The cities of East Asia such as Calcutta in India and Canton in China were known for its cosmopolitan, racial, socio-economic swirl. The novel Sea of Poppies also reconstructs the historical settings of the Great Experiment, which involved transport of South Asian natives of India as indentured labourers to Mauritius to work on the sugar plantations. The British played a significant part in both of these and to dominate the overseas campaigns the British East India Company involved the investments of Indian zamindars, seths of Gazipur and Bihar to carry its "shipment of Chalan opium” (p. 7) between India and China. Ibis which was earlier a slave ship, now when passing by Uttar Pradesh and Calcutta was also a transport vessel. The novel narrates the struggles and pains of many characters such as Deeti, Kalua, Munia, Ratna, Champa—from Gazipur, Benaras area; a Cornish Paulette Lambert who worked over her father's project in the botanical gardens of Sunderbans in Calcutta in association with a British couple Mr. and Mrs. Burnham, also escaped on Ibis in disguise of Indian woman coolie; Colonised convicted Raja Neel Rattan Haldar of Rashkali (called as Roger on Ibis) was a man of hope and spiritual leanings, whose mythical, emotional overtones and narrations caused sensitivity of forgetfulness towards pains among the insensible, hopeless, powerless common mass sailing in the ship Ibis towards Mauritius. The novel also throws light on the first opium war happened during the period 1839-1842 between Indians and Chinese, besides 
telling tales of the causes of Mutiny on the schooner Ibis before the war. The reason was they were miserably abused and maltreated by the Shipmasters, captains, and owners. These people as migrants in Edward Said's words enabled "Europe to advance securely and unmetaphorically upon the Orient" (Bhabha, 1994, p. 103). Such natives of South Asia along with many other rioters unaware of the death and birth (as the debusas or pulawars consisted of) sailed their destiny in the darkness through the Indian Ocean. Amitav Ghosh as a Bengali immigrant, a diaspora writer due to his intellectual leanings explores Indian modern history not only from the point of "epistemic status of South Asian identities" (Satya, 1997, pp. 202-234) within subcontinent India, but also in context of cross-cultural identities in the cosmopolitan, multicultural, polyglot world. He describes how the racial nexus of Fanquis-Ahens, White-Aliens and White-hated Parsees from Bombay used to control the trade of opium in India and in China; but also they linguistically and culturally influenced the psychic and social relations in context of positioning the subjects as elusive centre belonging to the category of labour class, underclass, subalterns, garmityas, South Asians, margins and so on. The racial nexus categorically reinvented and reconstructed the human moorings and engaged the whole world population with alterity and ambivalence both at their homeland and in their relations outside their homeland.

\section{Conclusion}

The Diaspora authors end their novels with an alternative for existence, which may not be to a path of upliftment, but certainly, they ensure in their plot the characters learn to endure and accept the situation or they become a part of the normal existential pattern. These inconclusive extrapolations in view of the new postcolonial paradigm regarding the position of cultural identities in the pre-colonial and early postcolonial times reflect the protagonists' clashes to surrender to each other's likes and dislikes, to assimilate their differences as regards cultural traditions of their imaginary homelands. The depiction of these imagined communities at transnational level open up the issue of cultural politics, reviewing history, geographic boundaries, and gender-orientation. Their evolution and emergence as the Diaspora intelligentsia community in the migrated place permeate the spirit of the modern nation-state on one hand; while on the other side these submissions have necessitated the discourse and practices of geopolitics for the global governance to provide central mechanisms of identity and human experience. It is apt to quote to validate the Diaspora's academic knowledge that Diaspora authors situate their engagement with geopolitics within the context of literature on the historical expansion of states, "techniques of governmentality" (Barry, et. al., 1996) and "histories of technology and territoriality” (Delanda, et. al., 1991). Diaspora writings create imbibe among the readers to have a deeper perspective and understanding of actual history behind the reasons of exile and migration. They make readers realize problems, expectations, self-actualization, besides suggesting and delivering the alternates to the problems in reality.

\section{References}

Bhabha, H. (1994). Location of Culture. London: Routledge.

Barry, A. O., et al. (1996). Foucault and Political Reason. Chicago: Univ. of Chicago Press.

Dalby, S. (1998). The Occulted Geopolitics ofNnation and Culture. In Rethinking Geopolitics. New York: Routledge.

Delanda, M., et al. (1991). War in the Age of Intelligent Machines. New York: Zone Books.

Desai, A. (1995). Journey to Ithaca. New York: Houghton Mifflin.

Desai, A. (1998). Baumgartner's Bombay. Oxford: Vintage.

Desai, A. (1999). Fasting, Feasting. London: Vintage.

Desai, A. (2001a). Bye-bye Blackbird. New Delhi: Orient. 
Desai, A. (2001b). Cry the Peacock. New Delhi: Orient Paperbacks.

Divakaruni, C. B. (2005). The Mistress of Spices. London; Black Swan.

Espinet, R. (2004). Part II Manahambre road. In The Swinging Bridge. India: Penguin Books.

Ghosh, A. (2008). Sea of Poppies. USA: John Murray.

Guerin, L. W., et al. (1992). The psychological approach: Freud. In A Handbook of Critical Approaches to Literature. New York: Oxford University Press.

Gupta, R. K. (2002). Introduction. The Novels of Anita Desai. New Delhi: Atlantic Publ.

Lahiri, J. (2003). The Namesake. Britain: Harper Collins Publ.

Somdatta, M. (2007). The City as Mindscape/: The Indian Immigrant Writer in the U.S.A. In N. E. Bharucha (Ed.), World Literature-Contemporary Postcolonial and Post-Imperial Literatures. New Delhi: Prestige.

Mehta, B. (2004). Introduction: Mapping Indo-Caribbean Women's Writing. In Diaporic (Dis)Locations: Indo-Caribbean Women Writers Negotiate the Kala Pani. Jamacia: University Press of the West Indies.

Merlin, L. (1998). Review; The Mistress of Spices. World Literature Today, 72(1), 207, JSTOR. Retrieved 25 Feb. 2015 from https://www.jstor.org/discover/10.2307/40153724?uid+4\&sid+21106755829393

Satya, M. P. (1997). Literary Theory and the Claims of Identity: Postmodernism, Objectivity, Multicultural Politics. USA: Cornell.

Nayak, B. (2003). The native and acquired selves of the tormented souls in the fictional world of Jumpa Lahiri. In B. Naikar (Ed.), Indian English literature. New Delhi: Atlantic Publ.

Procter, J. (2008). Cultural formations. In J. McLeod (Ed.), The Routledge Companion to Postcolonial Studies. London: Routledge.

Ravichandran, T. (2014). Entrapments at home and abroad in Anita Desai's Fasting, Feasting. Retrieved from http://home.iitk.ac.in/ trc/Anita\%20Desai-ff.pdf

Saha, A. (2014). "Loneliness in diasporic life as depicted by Anita Desai”. Retrieved from http://www.cerebration.org/amitshankarsaha.html

Said, E. (1978). Orientalism. USA: Pantheon Books.

Sarangi, J. (2005). Bond Without Bondage; Bharti Mukherjee and Jumpa Lahiri. In N. D. R. Chandra (Ed.), Contemporary Indian Writing in English-Critical Perceptions. New Delhi: Swarup \& Sons.

Showalter, E. (1985). Feminist criticism in the wilderness. In New Feminist Criticism. USA: Princeton.

Singh, J., \& Chhavi, G. (May 2015). Spices Action with the Internal World: The Mistress of Spices by Chitra Divakaruni. IJELLH, III(3).

Taneja, G. R. (1991). Anita Desai’s Baumgartner's Bombay: A Note. In K. Ayyappa Paniker (Ed.), Indian English literature since Independence. New Delhi: The Indian Association for English Studies. 